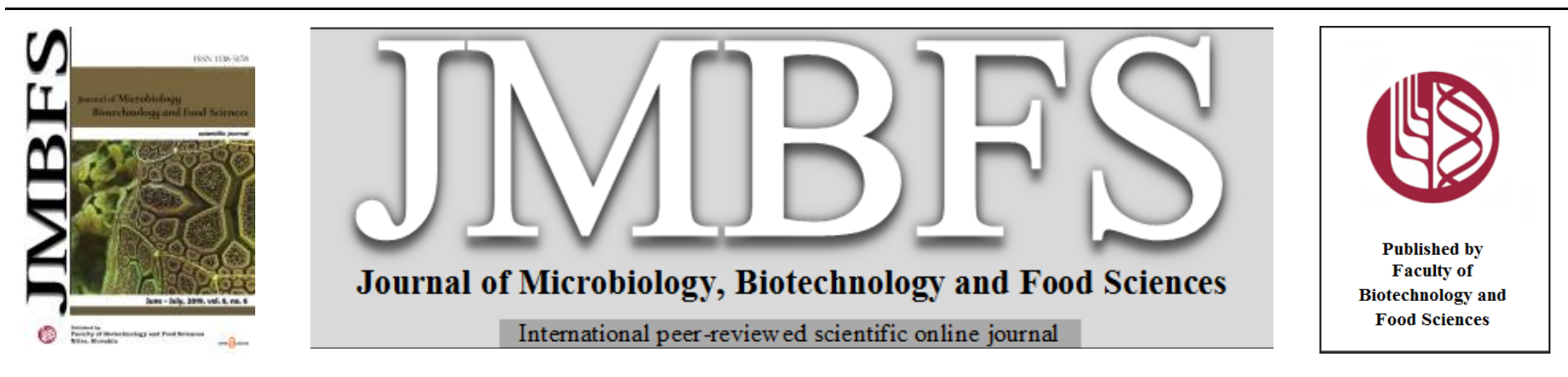

\title{
APPLICATION OF MALDI-TOF MASS SPECTROMETRY FOR IDENTIFICATION OF BACTERIA ISOLATED FROM TRADITIONAL SLOVAK CHEESE "PARENICA"
}

\author{
Miroslava Kačániová ${ }^{1}$ Simona Kunová2, Ludmila Nagyová ${ }^{3}$, Elena Horská3 ${ }^{3}$ Peter Haščík $k^{4}$, Margarita Terentjeva 5
}

\section{Address(es):}

${ }^{1}$ Slovak University of Agriculture in Nitra, Faculty of Biotechnology and Food Sciences, Department of Microbiology, Trieda Andreja Hlinku 2, 94976 Nitra, Slovakia, phone number: +421376414494.

${ }^{2}$ Slovak University of Agriculture, Faculty of Biotechnology and Food Sciences, Department of Food Safety and Hygiene, Trieda Andreja Hlinku 2, 94976 Nitra, Slovakia, phone number: +421376415807.

${ }^{3}$ Slovak University of Agriculture, Faculty of Economics and Management, Department of Marketing and Trade, Trieda Andreja Hlinku 2, 94976 Nitra, Slovakia, phone number: +421 376414494 .

${ }^{4}$ Slovak University of Agriculture in Nitra, Faculty of Biotechnology and Food Sciences, Department of Evaluation and Processing of Animal Products, Trieda Andreja Hlinku 2, 94976 Nitra, Slovakia, phone number: +421 376414708.

${ }^{5}$ Latvia University of Life Sciences and Technologies, Institute of Food and Environmental Hygiene, Faculty of Veterinary Medicine, Latvia K. Helmana iela 8, LV3004, Jelgava, Latvia.

*Corresponding author: miroslava.kacaniova@gmail.com

doi: 10.15414/jmbfs.2019.8.6.1294-1297

\section{ARTICLE INFO}

Received 9. 11. 2018

Revised 12. 2. 2019

Accepted 14. 2. 2019

Published 1. 6. 2019

Regular article

oPEN $\odot$ ACCESS

\begin{abstract}
In this study, the cultivable population of bacteria from a traditional Slovak cheese "Parenica" made from cow milk were identified using MALDI-TOF mass spectrometry (MS). A total of 100 "Parenica" cheese packages from four producers were examined, including $\mathrm{n}=50$ smoked and $\mathrm{n}=50$ non-smoked cheese samples. The lactic acid bacteria (LAB) were cultured on MRS, APT and MSE agars at 30 ${ }^{\circ} \mathrm{C}$, coliform bacteria on VRBL agar at $37{ }^{\circ} \mathrm{C}$, total count of bacteria (TCB) on Plate count agar at $30{ }^{\circ} \mathrm{C}$ and enterococci on Enterococcus selective agar at $37^{\circ} \mathrm{C}$. Gram-positive and gram-negative strains were subjected to identification by MALDI-TOF MS profiling. MALDI-TOF MS identification revealed four genera belonging to LAB including Lactococcus, Lactobacillus, Enterococcus and Leuconostoc. Lactobacillus was the most represented genus with seven species: Lactobacillus curvatus (L. curvatus), L. delbrueckii, L. fermentum, L. casei, L. paraplantarum, L. plantarum and L. sakei.. Escherichia coli, Enterobacter asburiae, Klebsiella oxytoca and K. pneumoniae were the most identified bacteria species from Enterobacteriales order.
\end{abstract}

Keywords: bacteria, mass spectrometry, identification, Slovak "Parenica" cheese

\section{INTRODUCTION}

Manufacture of most of cheese varieties involves a combining of four ingredients: milk, rennet, microorganisms and salt, which are processed. The common steps of cheese-making include gel formation, curd whey expulsion, acid production and salt addition, followed by a period of ripening. A variation in ingredient blends and processing has led to the evolution of cheese varieties. While variations in processing parameters such as processing temperature and curd handling techniques play a major role in production of each cheese type, but the cheese microflora play a critical and pivotal role in the development of the unique characteristics of each cheese variety (Beresford et al., 2001). Traditional raw-milk cheeses are highly valued for their flavors, while large-scale products are often perceived by the consumer as "boring" (Law, 2001). This difference is a consequence of the elimination of raw milk microflora by pasteurization that has a key role in flavor development. To compensate the sensory characteristics of product the food industry looks for alternative LAB (Lactic Acid Bacteria) cultures capable of improving products flavor (Leroy and De Vuyest, 2004). However, the LAB are only a part of the complete microflora of raw milk (Kongo et al., 2007). Complex approach then the addition of LAB is associated to other technological methods such as pressing allows the production of diverse of traditional cheeses (Parguel, 2011). The raw-milk microbiota also represents the contamination from the environment (air, utensils, the animal skin), and the load and its diversity will vary with location, season and livestock species and milking procedures.

Food spoilage is an enormous economic worldwide problem. Approximately onefourth of the world's food supply is lost through microbial activity alone (Huis in't Veld, 1998). Milk is highly nutritious food that serves as an excellent growth medium for a wide range of microorganisms (Ruegg, 2003; Rajagopal et al., 2005). The microbiological quality of milk and dairy products is influenced by the initial microbiota of raw milk, the processing conditions, and post-heat treatment contamination (Richter et al., 1992). Undesirable microbiota that can cause a spoilage of dairy products includes Gram-negative psychrotrophs, coliforms, lactic acid bacteria, yeasts, and molds. In addition, the various pathogens of public health concern such as Salmonella spp., Listeria monocytogenes, Campylobacter jejuni, Yersinia enterocolitica, pathogenic strains of Escherichia coli and enterotoxigenic strains of Staphylococcus aureus may also be found in milk and dairy products (Tatini and Kauppi, 2003; AlSahlany, 2016; Verma and Niamah, 2017). This is one of the reasons why the increased emphasis should be focused on the microbiological examination of milk and dairy foods. Microbiological analyses of milk and milk products are critical for assessment of quality and safety, conformation with standards and specifications, and regulatory compliance (Vasavada, 1993).

The aim of this study was to evaluate microbiological quality of the traditional Slovak non-smoked and smoked cheese "Parenica" made from cow milk and to identify bacterial strains with MALDI-TOF MS Biotyper.

\section{MATERIAL AND METHODS}

\section{Samples}

There were 50 samples of the Slovak national cheese "Parenica" examined in this study. The cheese samples included non-smoked cheese $(\mathrm{n}=25)$ and smoked cheese $(n=25)$. Additionally, a total of 50 cow milk cheese samples from the Slovak producers located in the western and the middle part of Slovakia were collected (Bánovce nad Bebravou, Liptovský Mikuláš, Červený Kameň, Važec). All samples were placed in sterile sample containers and transported to laboratory on ice for microbiological investigations. Samples were kept in a refrigerator $\left(4 \pm 1^{\circ} \mathrm{C}\right)$ until the testing began.

The primary dilution of the milk products was made for preparing the samples for testing. For that a $5 \mathrm{ml}$ of sample material was added to $45 \mathrm{ml}$ of $0.87 \%$ sterile 
saline, then the serial dilutions $\left(10^{-1}\right.$ to $\left.10^{-4}\right)$ were done and a $100 \mu 1$ of each dilution was plated out.

\section{Isolation of total count of bacteria}

Plate count agar (PCA, Sigma-Aldrich ${ }^{\circledR}$, St. Louis, USA) for total count bacteria enumeration was used. Inoculated plates were incubated at $30{ }^{\circ} \mathrm{C}$ for $24-48 \mathrm{~h}$ and then examined for the presence of bacterial colonies.

\section{Isolation of coliform bacteria}

Violet red bile lactose agar (VRBGA, Sigma-Aldrich ${ }^{\circledR}$, St. Louis, USA) for enumeration of coliforms bacteria was used. Inoculated plates were incubated at $37^{\circ} \mathrm{C}$ for $24-48 \mathrm{~h}$ and then examined for the presence of typical colonies.

\section{Isolation of enterococci}

Enterococcus selective agar (ESA, Sigma-Aldrich ${ }^{\circledR}$, St. Louis, USA) for enumeration of enterococci was used. Inoculated plates were incubated at $37{ }^{\circ} \mathrm{C}$ for 24-48 $\mathrm{h}$ and then examined for the presence of typical colonies.

\section{Isolation of Lactic Acid Bacteria (LAB)}

MRS (Main Rogose agar, Oxoid, UK), MSE (Mayeux, Sandine and Elliker in 1962, Oxoid, UK), and APT (All Purpose TWEEN ${ }^{\circledR}$ agar, Oxoid, UK ) agar were used for enumeration of LAB including lactobacilli, leuconostocs and lactic acid streptococci as well as other microorganisms with high requirements for thiamine (Sigma-Aldrich ${ }^{\circledR}$, St. Louis, USA). Inoculated agars were incubated at $30{ }^{\circ} \mathrm{C}$ for $72 \mathrm{~h}$ anaerobically and then the bacterial growth was evaluated.

\section{Sample preparation and MALDI-TOF MS measurement}

Prior to identification, the bacterial colonies were subcultured on TSA agar (Tryptone Soya Agar, Oxoid, UK) at $37^{\circ} \mathrm{C}$ for $18-24 \mathrm{~h}$. One colony of each bacterial isolate was selected. Subsequently, the identification was performed using the Maldi TOF MS Biotyper described by Kluga et al. (2017). Totally, a number of 512 isolates were identified with score higher than 2 .

\section{RESULTS AND DISCUSSION}

\section{Number of isolated bacterial group}

Cheeses are fermented dairy products whose manufacturing involves different types of bacteria (Montel et al., 2014; Irlinger et al., 2015). Cheese producing is a process when a nutrient-rich substrate as milk is colonized by adventitious and deliberately inoculated microorganisms. Two different habitats of bacteria in cheese may be considered: the interior of the cheese and the cheese rind. The rind microbiota can be considered as an interesting model system for the field of ecosystems biology (Wolfe et al., 2014).

Total count of bacteria in non-smoked cheese ranged from 5.25 to $5.58 \log \mathrm{cfu} . \mathrm{g}$ 1. Enterococci were not identified in the studied samples. Coliform bacteria counts ranged from 1.25 to $1.80 \log$ cfu. $\mathrm{g}^{-1}$, but lactic acid bacteria counts ranged from 4.12 to $4.51 \log \mathrm{cfu}^{-1} \mathrm{~g}^{-1}$. Total count of bacteria in smoked cheese ranged from 5.45 to $5.85 \mathrm{log}$ cfu.g $^{-1}$. Enterococci and coliform bacteria number of bacteria were not identified in the samples studied. Lactic acid bacteria counts ranged from 4.12 to $4.48 \log \mathrm{cfu} . \mathrm{g}^{-1}$.

Kačániová et al., (2018) found similar results in cheese samples, and the total count of bacteria in non-smoked cheese ranged from 3.15 to $3.58 \mathrm{log} \mathrm{cfu}^{-1} \mathrm{~g}^{-1}$ Enterococci were not identified in the studied samples. Coliform bacteria count ranged from 1.12 to $1.52 \log$ cfu. $^{-1}$, but lactic acid bacteria counts ranged from 2.12 to $2.51 \log$ cfu. $\mathrm{g}^{-1}$. Total count of bacteria in smoked cheese ranged from 2.14 to $2.58 \log \mathrm{cfu}^{-1} \mathrm{~g}^{-1}$. Enterococci and coliforms bacteria were not identified in the studied samples. Lactic acid bacteria counts ranged from 1.12 to $2.18 \mathrm{log}$ cfu.g $\mathrm{g}^{-1}$.

Total counts of bacteria are the most useful indicator for the overall microbiological quality of the cheese. High viable count often indicates a contamination of the raw material, unsatisfactory sanitation, or unsuitable time and temperature during storage and/or production. The attention has been focused on coliform bacteria because of their public health importance. Coliforms are widely distributed in nature. They gain entry to milk and milk products through the water supply, equipment, unhygienic conditions of production and handling (El-Leboudy et al., 2014).

\section{Isolated bacteria with MALDI-TOF MS Biotyper}

Table 1 Isolated species of bacteria from smoked and non-smoked cheese "Parenica"

\begin{tabular}{|c|c|c|}
\hline Family & Genera & Species \\
\hline Moraxellaceae & Acinetobacter & Acinetobacter pittii \\
\hline Moraxellaceae & Acinetobacter & Acinetobacter baumannii \\
\hline Moraxellaceae & Acinetobacter & Acinetobacter junii \\
\hline Bacillaceae & Bacillus & Bacillus cereus \\
\hline Bacillaceae & Bacillus & Bacillus pumilus \\
\hline Bacillaceae & Bacillus & Bacillus thuringiensis \\
\hline Brevibacteriaceae & Brevibacterium & Brevibacterium casei \\
\hline Flavobacteriaceae & Chryseobacterium & Chryseobacterium oranimense \\
\hline Enterobacteriaceae & Citrobacter & Citrobacter braakii \\
\hline Enterobacteriaceae & Citrobacter & Citrobacter youngae \\
\hline Burkholderiaceae & Cupriavidus & Cupriavidus metallidurans \\
\hline Enterobacteriaceae & Enterobacter & Enterobacter asburiae \\
\hline Enterobacteriaceae & Enterobacter & Enterobacter cloacae \\
\hline Enterobacteriaceae & Enterococcus & Enterococcus durans \\
\hline Enterococcaceae & Enterococcus & Enterococcus faecalis \\
\hline Enterococcaceae & Enterococcus & Enterococcus faecium \\
\hline Enterococcaceae & Enterococcus & Enterococcus italicus \\
\hline Enterobacteriaceae & Escherichia & Escherichia coli \\
\hline Enterobacteriaceae & Ewingella & Ewingella americana \\
\hline Acetobacteraceae & Gluconobacter & Gluconobacter cerinus \\
\hline Enterobacteriaceae & Hafnia & Hafnia alvei \\
\hline Micrococcaceae & Kocuria & Kocuria kristinae \\
\hline Enterobacteriaceae & Klebsiella & Klebsiella oxytoca \\
\hline Enterobacteriaceae & Klebsiella & Klebsiella pneumoniae \\
\hline Lactobacillaceae & Lactobacillus & Lactobacillus curvatus \\
\hline Lactobacillaceae & Lactobacillus & Lactobacillus delbruckii \\
\hline Lactobacillaceae & Lactobacillus & Lactobacillus fermentum \\
\hline Lactobacillaceae & Lactobacillus & Lactobacillus paracasei \\
\hline Lactobacillaceae & Lactobacillus & Lactobacillus paraplantarum \\
\hline Lactobacillaceae & Lactobacillus & Lactobacillus plantarum \\
\hline Lactobacillaceae & Lactobacillus & Lactobacillus sakei \\
\hline Streptococcaceae & Lactococcus & Lactococcus lactis \\
\hline Leuconostocaceae & Leuconostoc & Leuconostoc mesenteroides \\
\hline Staphylococcaceae & Macrococcus & Macrococcus caseolyticus \\
\hline Micrococcaceae & Micrococcus & Micrococcus luteus \\
\hline Enterobacteriaceae & Pantoea & Pantoea agglomerans \\
\hline Lactobacillaceae & Pediococcus & Pediococcus pentosaceus \\
\hline Enterobacteriaceae & Pluralibacter & Pluralibacter gergoviae \\
\hline Pseudomonadaceae & Pseudomonas & Pseudomonas rhodesiae \\
\hline Enterobacteriaceae & Rahnella & Rahnella aquatilis \\
\hline Enterobacteriaceae & Raoultella & Raoultella ornithinolytica \\
\hline Enterobacteriaceae & Raoultella & Raoultella planticola \\
\hline Rhizobiaceae & Rhizobium & Rhizobium radiobacter \\
\hline Enterobacteriaceae & Serratia & Serratia liquefaciens \\
\hline Sphingomonadaceae & Sphingomonas & Sphingomonas melonis \\
\hline Sphingomonadaceae & Sphingomonas & $\begin{array}{l}\text { Sphingomonas } \\
\text { parapaucimobilis }\end{array}$ \\
\hline Staphylococcaceae & Staphylococcus & Staphylococcus epidermidis \\
\hline Staphylococcaceae & Staphylococcus & Staphylococcus haemoliticus \\
\hline Staphylococcaceae & Staphylococcus & Staphylococcus saprophyticus \\
\hline Staphylococcaceae & Staphylococcus & Staphylococcus succinus \\
\hline Staphylococcaceae & Staphylococcus & Staphylococcus warneri \\
\hline Streptococcaceae & Streptococcus & Streptococcus equinus \\
\hline Streptococcaceae & Streptococcus & $\begin{array}{l}\text { Streptococcus } \\
\text { salivarius_ssp._thermophilus }\end{array}$ \\
\hline
\end{tabular}


Table 2 Number of isolates identified with MALDI-TOF MS Biotyper in cheese

\begin{tabular}{|c|c|c|c|}
\hline Microorganisms & $\begin{array}{c}\text { Non-smoked } \\
\text { cheese }\end{array}$ & $\begin{array}{c}\text { Smoked } \\
\text { cheese }\end{array}$ & Total \\
\hline Acinetobacter pittii & 5 & 2 & 7 \\
\hline Acinetobacter baumannii & 10 & 10 & 20 \\
\hline Acinetobacter junii & 2 & 2 & 4 \\
\hline Chryseobacterium oranimense & 2 & 2 & 4 \\
\hline Citrobacter braakii & 4 & 4 & 8 \\
\hline Citrobacter youngae & 4 & 4 & 8 \\
\hline Cupriavidus metallidurans & 2 & 1 & 3 \\
\hline Enterobacter asburiae & 8 & 9 & 17 \\
\hline Enterobacter cloacae & 4 & 3 & 7 \\
\hline Escherichia coli & 15 & 12 & 27 \\
\hline Ewingella americana & 2 & 2 & 4 \\
\hline Gluconobacter cerinus & 1 & 5 & 6 \\
\hline Hafnia alvei & 8 & 2 & 10 \\
\hline Klebsiella oxytoca & 10 & 12 & 22 \\
\hline Klebsiella pneumoniae & 12 & 12 & 24 \\
\hline Pantoea agglomerans & 2 & 2 & 4 \\
\hline Pluralibacter gergoviae & 2 & 2 & 4 \\
\hline Pseudomonas rhodesiae & 2 & 2 & 4 \\
\hline Rahnella aquatilis & 3 & 2 & 5 \\
\hline Raoultella ornithinolytica & 3 & 3 & 6 \\
\hline Raoultella planticola & 1 & 1 & 2 \\
\hline Rhizobium radiobacter & 2 & 2 & 4 \\
\hline Serratia liquefaciens & 4 & 4 & 8 \\
\hline Sphingomonas melonis & 3 & 3 & 6 \\
\hline $\begin{array}{l}\text { Sphingomonas } \\
\text { parapaucimobilis }\end{array}$ & 2 & 2 & 4 \\
\hline Gram-negative bacteria & 113 & 105 & 218 \\
\hline Microorganisms & $\begin{array}{l}\text { Non- smoked } \\
\text { cheese }\end{array}$ & $\begin{array}{c}\text { Smoked } \\
\text { cheese }\end{array}$ & Total \\
\hline Bacillus cereus & 5 & 2 & 7 \\
\hline Bacillus pumilus & 4 & 2 & 6 \\
\hline Bacillus thuringiensis & 1 & 2 & 3 \\
\hline Brevibacterium casei & 3 & 3 & 6 \\
\hline Enterococcus durans & 3 & 5 & 8 \\
\hline Enterococcus faecalis & 4 & 4 & 8 \\
\hline Enterococcus faecium & 5 & 5 & 10 \\
\hline Enterococcus italicus & 1 & 1 & 2 \\
\hline Kocuria kristinae & 2 & 2 & 4 \\
\hline Lactobacillus curvatus & 15 & 10 & 25 \\
\hline Lactobacillus delbruckii & 15 & 15 & 30 \\
\hline Lactobacillus fermentum & 10 & 10 & 20 \\
\hline Lactobacillus paracasei & 15 & 15 & 30 \\
\hline Lactobacillus paraplantarum & 10 & 10 & 20 \\
\hline Lactobacillus plantarum & 10 & 10 & 20 \\
\hline Lactobacillus sakei & 15 & 12 & 27 \\
\hline Lactococcus lactis & 10 & 9 & 19 \\
\hline Leuconostoc mesenteroides & 5 & 5 & 10 \\
\hline Macrococcus caseolyticus & 3 & 3 & 6 \\
\hline Micrococcus luteus & 4 & 4 & 8 \\
\hline Pediococcus pentosaceus & 2 & 2 & 4 \\
\hline Staphylococcus epidermidis & 2 & 2 & 4 \\
\hline Staphylococcus haemoliticus & 2 & 2 & 4 \\
\hline Staphylococcus saprophyticus & 2 & 3 & 5 \\
\hline Staphylococcus succinus & 1 & 2 & 3 \\
\hline Staphylococcus warneri & 1 & 2 & 3 \\
\hline Streptococcus equinus & 2 & 2 & 4 \\
\hline $\begin{array}{l}\text { Streptococcus salivarius ssp. } \\
\text { thermophilus }\end{array}$ & 8 & 2 & 10 \\
\hline Gram-positive bacteria & 149 & 145 & 294 \\
\hline Total & 262 & 250 & 512 \\
\hline
\end{tabular}

A total of 53 species of 30 bacterial genera (18 gram-negative $\mathrm{G}^{-}$and $12 \mathrm{Gram}$ positive $\mathrm{G}^{+}$) were identified in smoked and non-smoked cheese by MALDI-TOF Mass Spectrometry. The percentage representation of each bacterial group (G and $\mathrm{G}^{+}$) were $42.58 \%$ for $\mathrm{G}^{-}\left(218\right.$ isolates) (and $57.42 \%$ for $\mathrm{G}^{+}$(294 isolates). (). Isolated species of bacteria from smoked and non-smoked cheese "Parenica" are shown in Table 1.

Percentages of the number of isolates of each species for $\mathrm{G}^{-}$and $\mathrm{G}^{+}$are shown in Table 2. The most abundant $\mathrm{G}^{-}$bacterium was Escherichia coli, Klebsiella oxytoca and Klebsiella pneumoniae. Lactobacillus was the most abundant within 12 different species of $\mathrm{G}^{+}$bacteria with Lactobacillus casei, L. delbrueckii and $L$. sakei were the most distributed.

Nevertheless, many LAB species were found in both kinds of French cheeses, e.g. L. plantarum, $L$. paracasei, $L$. curvatus, $L$. rhamnosus, $L$. fructivorans, $L$ parabuchneri, L. brevis (Nacef et al., 2017). As previously were reported, some Lactobacilli are present in the natural microflora of dairy products and arise from animals, farms and dairies: $L$. casei $\mathrm{ssp}$. casei/L. paracasei $\mathrm{ssp}$. paracase $i, L$ rhamnosus, L. plantarum, L. fermentum, L. brevis, L. buchneri, L. curvatus, $L$. acidophilus and $L$. pentosus (Corbo et al., 2001, Gobbetti et al., 2002, Medina et al., 2001). Lactobacilli, especially $L$. curvatus, represents a type of milk microbiota that is resistant to pasteurization. Moreover the presence of LAB could be also attributed to contamination occurring after pasteurization (Martley and Crow, 1993).

Kačániová et al. (2018) found in microbiological analysis of 50 cheese samples three main groups of microorganisms: gram-negative and gram-positive bacteria and fungi. Althogether, 47 species of 18 bacterial genera (17 Gram negative G and 12 Gram positive $\mathrm{G}^{+}$) and 10 species of yeasts of 5 genera were identified with MALDI-TOF Mass Spectrometry. The percentage representation of each microbial group $\left(\mathrm{G}^{-}, \mathrm{G}^{+}\right.$and yeasts) from a total of 669 isolates, reached the following values: 166 isolates of $\mathrm{G}^{-}(24.81 \%), 297$ isolates of $\mathrm{G}^{+}(44.39 \%)$, and 206 isolates of yeasts $(30.79 \%)$.

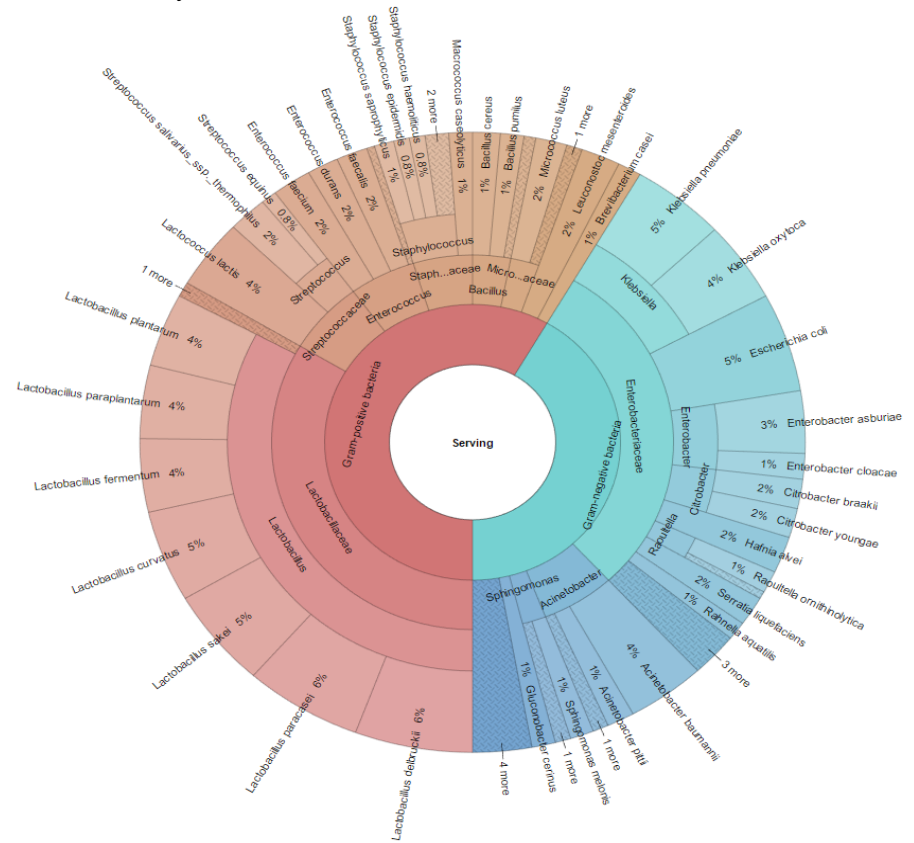

Figure 1 Percentage of isolated bacterial species in cheese samples

Mounier et al. (2006) found out that the microorganisms that developed on the cheese surface were an adventitious microflora from the cheese environment (brine, ripening shelves, and personnel) which rapidly outnumbered the commercial cultures. Several hypotheses have been advanced to explain these findings. These ripening cultures may be unfit for the cheese habitat, or negative interactions may occur between them and the adventitious microflora (Maoz $e$ al., 2003).

\section{CONCLUSION}

Microbiological analysis of 100 cheese samples revealed the two main groups of microorganisms comprising 53 species of 30 bacterial genera (18 Gram-negative $\mathrm{G}^{-}$and 12 Gram-positive $\mathrm{G}^{+}$) identified with MALDI-TOF Mass Spectrometry. The percentage representation of each bacterial group $\left(\mathrm{G}^{-}\right.$and $\left.\mathrm{G}^{+}\right)$were $42.58 \%$ (218 isolates of $\mathrm{G}^{-}$) (and $57.42 \%$ (294 isolates of $\mathrm{G}^{+}$). Fast microbial identification is becoming increasingly necessary in industry to improve microbial control, reduce biocide consumption, to avoid cost-intensive recall of contaminated products and damage to brand reputation. While MALDI-TOF-MS has revolutionized speed and precision of microbial identification for clinical isolates, in contrast few performance studies have been published so far focusing on suitability for particularly industrial applications.

Acknowledgement: Work was supported by the grants APVV-16-0244 "Qualitative factors affecting the production and consumption of milk and cheese".

\section{REFERENCES}

AL-SAHLANY,S.T.G. 2016. Effect of Mentha piperita essential oil against Vibrio spp. isolated from local cheeses. Pakistan journal of food sciences, 26(2), 65-71.

BERESFORD, T.P., FITZSIMONS, N.A., BRENNAN, N.L., COGAN, T.M. 2001. Recent advances in cheese microbiology. International Dairy Journal, 11(4-5), 259-274. https://doi.org/10.1016/s0958-6946(01)00056-5

CORBO, M.R., ALBENZIO, M., DE ANGELIS, M., SEVI, A, GOBBETTI, M. 2001. Microbiological and biochemical properties of canestrato pugliese hard cheese supplemented with bifidobacteria. Journal of Dairy Science, 84(3), 551561. https://doi.org/10.3168/jds.s0022-0302(01)74507-9 
EL-LEBOUDY, A.A., AMER, A.A., YOUSSEF, M.R. 2014. Assessment of sanitary measures of ras cheese in manufacturing dairy plant in Alexandria Governorate. Alexandria Journal of Veterinary Sciences, 40(1), 87-94. https://doi.org/10.5455/ajvs.48184

GOBBETTI, M., STEPANIAK, L., DE ANGELIS, M., CORSETTI, A., DI CAGNO, R. 2002. Latent bioactive peptides in milk proteins: proteolytic activation and significance in dairy processing. Critical Reviews in Food Science and Nutrition, 42(3), 223-239. https://doi.org/10.1080/10408690290825538

HUIS IN'T VELD, J.H.J. 1996. Specific Spoilage Organisms. International Journal of Food Microbiology, 33(1), 7. https://doi.org/10.1016/s01681605(96)90008-2

IRLINGER, F., LAYEC, S., HÉLINCK, S., DUGAT-BONY, E. 2015. Cheese rind microbial communities: diversity, composition and origin. FEMS Microbiology Letters. 362(2), 1-11. https://doi.org/10.1093/femsle/fnu015

KAČÁNIOVÁ, M, TERENTJEVA, M., KUNOVÁ, S., NAGYOVÁ, L., HORSKÁ, E., HAŠČÍK, P., KLUZ, M., PUCHALSKI, C. 2018. MALDI TOF MS Biotyper identification of Slovak cheese microflora. Acta Agraria Debreceniensis, 227-239.

KLŪGA, A., TERENTJEVA, M., KÁNTOR, A., KLUZ, M., PUCHALSKI, C., KAČÁNIOVÁ, M. 2017. Antibacterial activity of Melissa officinalis L., Mentha piperita L., Origanum vulgare L. and Malva mauritiana against bacterial microflora isolated from fish. Advanced Research in Life Sciences, 1, 75-80. https://doi.org/10.1515/arls-2017-0013

KONGO, J.M., HO, A.J., MALCATA, F.X., WIEDMANN, M. 2007. Characterization of dominant lactic acid bacteria isolated from Sao Jorge cheese using biochemical and ribotyping methods. Journal of Applied Microbiology, 103(5), 1838-1844. https://doi.org/10.1111/j.1365-2672.2007.03423.x

LAW, B. A. 2001. Controlled and accelerated cheese ripening: the research base for new technology. International Dairy Journal, 11(4-7), 383-398. https://doi.org/10.1016/s0958-6946(01)00067-X

LEROY, F., DE VUYST, L. 2004. Lactic acid bacteria as functional starter cultures for the food fermentation industry. Food Science and Technology, 15(2), 67-78. https://doi.org/10.1016/j.tifs.2003.09.004

MAOZ, A., MAYR, R., SCHERER, S. 2003. Temporal stability and biodiversity of two complex antilisterial cheese-ripening microbial consortia. Applied and $\begin{array}{llll}\text { Environmental } & \text { Microbiology, } & \text { 69(7), } & \text { 4012-4018. }\end{array}$ https://doi.org/10.1128/aem.69.7.4012-4018.2003

MARTLEY, F.G., CROW, V.L. 1993. Interactions between non-starter microorganisms during cheese manufacture and ripening

International Dairy Journal, 3 (4-6), 461-483. https://doi.org/10.1016/09586946(93)90027-w

MEDINA, R., KATZ, M., GONZALEZ, S., OLIVER, G. 2001. Characterization of the lactic acid bacteria in ewe's milk and cheese from northwest Argentina. Journal of Food Protection, 64(4), 559-563. https://doi.org/10.4315/0362-028x64.4.559

MONTEL, M., BUCHIN, C., MALLET, S., DELBES-PAUS, A., VUITTON, C. DESMASURES, N. 2014. Traditional cheeses: rich and diverse microbiota with associated benefits. International Journal of Food Microbiology, 177, 136-154.

https://doi.org/10.1016/j.ijfoodmicro.2014.02.019

MOUNIER, J., GOERGES, S., GELSOMINO, R., VANCANNEYT, R., VANDEMEULEBROECKE, K., HOSTE, B., BRENNAN, N.M., SCHERER, S., SWINGS, J., FITZGERALD, G.F., COGAN, T.M. 2006. The sources of the adventitious microflora of a smear-ripened cheese. Journal of Applied Microbiology, 101(3), 668-681. https://doi.org/10.1111/j.13652672.2006.02922.x

NACEF, M., CHEVALIER, M., CHOLLET, S, DRIDER, D., FLAHAU, CH. 2017. MALDI-TOF mass spectrometry for the identification of lactic acid bacteria isolated from a French cheese: The Maroilles. International Journal of Food Microbiology, 247, 2-8. https://doi.org/10.1016/j.ijfoodmicro.2016.07.005 PARGUEL, P. 2004. "Milk flores", group Malbuisson (Doubs), 1-7.

RAJAGOPAL, M., WERNER, B.G., HOTCHKISS, J.H. 2005. Lowpressure $\mathrm{CO}_{2}$ storage of raw milk: Microbiological effects. Journal of Dairy Science, 88(9), 3130-3138. https://doi.org/10.3168/jds.s0022-0302(05)72995-7

RICHTER, R.L., LEDFORD, R.A., MURPHY, S.C. 1992. Compendium of methods for the microbiological examination of foods. Washington DC: American Public Health Association, 837-856. ISBN: 0875531733.

RUEGG, P.L. 2003. Practical food safety interventions for dairy production Journal of Dairy Science, 86, E1-E9. https://doi.org/10.3168/jds.s00220302(03)74034-X

TATINI, S.R., KAUPPI, K.L. 2002. Analysis/Microbiological Analyses. Encyclopedia of Dairy Sciences. 1, 74-79. https://doi.org/10.1016/B0-12-2272358/00021-3

VASAVADA, P.C. 1993. Rapid methods and automation in dairy microbiology. Journal of Dairy Science, 76 (10), 3101-3113. https://doi.org/10.3168/jds.s00220302(93) 77649-3

VERMA, D. K., NIAMAH, A. K. 2017. Microbial intoxication in dairy food products. In: Microorganisms in Sustainable Agriculture, Food, and the Environment. Apple Academic Press pp. 165-192. https://doi.org/10.1201/9781315365824-6
WOLFE, B.E., BUTTON, J.E., SANTARELLI, M., DUTTON, R.J. 2014. Cheese rind communities provide tractable systems for in situ and in vitro studies of microbial diversity. Cell. 158(2), 422-433. https://doi.org/10.1016/j.cell.2014.05.041 